Jurnal Manajemen Kesehatan Yayasan RS. Dr. Soetomo Vol.4 No.2 Oktober 2018

Print ISSN 2477-0140 Online ISSN 2581-219X

www.jurnal.stikes-yrsds.ac.id

\title{
Pengaruh Sikap Kader Kesehatan Terhadap Pengendalian Demam Berdarah Dengue
}

\section{Effect Of Health Cadre Attitude To Control Dengue Hemorrhagic Fever}

\author{
Sri Sularsih Endartiwi*, Desya Amirti Sofarina* \\ ${ }^{*}$ STIKES Surya Global Yogyakarta \\ E-mail : tiwinafla2@gmail.com
}

\begin{abstract}
ABSTRAK
Penyebaran penyakit DBD di Kabupaten Bantul Tahun 2015 terdapat di seluruh wilayah kerja puskesmas yaitu sebanyak 1441 kasus dengan Incidence Rate (IR) 1,48\%. Hal ini mengalami peningkatan dari Tahun 2014 yang hanya terdapat 622 kasus (IR 0,64\%). 27 wilayah kerja puskesmas di Bantul, kejadian paling tinggi terjadi di wilayah kerja Puskesmas Kasihan II Bantul sebanyak 174 kasus. Bulan Januari-September 2016 yaitu sebanyak 1582 kasus. Penelitian ini bertujuan untuk membuktikan adanya pengaruh antara sikap kader kesehatan terhadap perannya dalam pengendalian demam berdarah dengue di wilayah kerja Puskesmas Kasihan II Bantul. Jenis penelitian ini adalah penelitian survei dengan menggunakan mix method dengan rancangan penelitian crosssectional. Jumlah sebanyak 175 kader di Desa Ngestiharjo wilayah kerja Puskesmas Kasihan II Kabupaten Bantul. Subjek penelitian ini sebanyak 3 orang kader, 3 orang masyarakat dan 2 orang pegawai puskesmas dilakukan wawancara mendalam (indept interview). Penelitian dilaksanakan di Wilayah Kerja Puskesmas Kasihan II Kabupaten Bantul. Penelitian dilakukan pada Februari 2017. Hasil penelitian ini menunjukkan bahwa sikap aktif dari kader dapat mempengaruhi perilaku pengendalian demam berdarah dengue di Desa Ngestiharjo wilayah kerja Puskesmas Kasihan II Bantul. Hal ini ditunjukkan dengan hasil uji kendall's tau yang memiliki p-value 0,006.
\end{abstract}

\section{Kata Kunci : Sikap Kader, Pengendalian Demam Berdarah Dengue}

\section{ABSTRACT}

Bantul Health District Office, the spread of dengue fever in 2015 is found in all working areas of puskesmas that is 1441 cases (IR 1.48\%). This is an increase from 2014 with only 622 cases (IR 0.64\%). 27 working areas of healthcare in Bantul, the highest incidence occurred in the working area of Kasihan II Bantul healthcare as many as 174 cases. In January-September 2016, there were 1582 cases. This study aims to prove the influence of health cadre attitude toward its role in dengue hemorrhagic control in the working area of Kasihan II healthcare Bantul.The type of this research is survey research using mix method with cross-sectional research design. A total of 171 cadres in Ngestiharjo village as working area of Kasihan II healthcare Bantul. Subject of this study as many as 3 peoples cadres, 3 peoples and 2 people employee puskesmas conducted in-depth interviews. The research will be conducted in the work area of Kasihan II healthcare Bantul. The research will be conducted in February, 2017. The results of this study indicate that the active attitude of the 
cadres can influence the control behavior of dengue hemorrhagic fever in Ngestiharjo village working area of Kasihan II healthcare Bantul. This is indicated by the test results of kendall's tau which has p-value 0.006.

Keywords: Cadres Attitude, Dengue Hemorrhagic Control

\section{PENDAHULUAN}

Daerah Istimewa Yogyakarta (DIY) terdapat 5 kabupaten, jumlah kasus DBD dari tahun 2011-2013 mengalami fluktuatif. Pada tahun 2011 jumlah kasus DBD di Provinsi DIY adalah 1012, dengan Incidence Rate 28,8 per 100.000 penduduk. Pada tahun 2012 terjadi penurunan 12 kasus, sehingga jumlah kasus DBD di DIY adalah 1000, dengan angka Incidence Rate 7,5 per 100.000 penduduk. Lalu pada tahun 2013 meningkat tajam yaitu 2912 (DINKES Provinsi DIY, 2014).

Berdasarkan data yang didapatkan dari Dinas Kesehatan Bantul, penyebaran penyakit DBD tahun 2015 terdapat di seluruh wilayah kerja puskesmas yaitu sebanyak 1441 kasus dengan Incidence Rate (IR 1,48\%). Hal ini mengalami peningkatan dari tahun 2014 hanya terdapat 622 kasus (IR 0, 64 \%). Dari 27 wilayah kerja puskesmas di Bantul, kejadian paling tinggi terjadi di wilayah kerja Puskesmas Kasihan II Bantul sebanyak 174 kasus. Untuk data penyakit demam berdarah dengue tahun 2016 dari Bulan Januari - September yaitu sebanyak 1582 kasus, hal ini mengalami peningkatan dari tahun sebelumnya (DINKES Kabupaten Bantul, 2015).

Berdasarkan hasil studi pendahuluan dengan melakukan wawancara kepada 10 kader kesehatan diperoleh bahwa 6 di antaranya masih belum sepenuhnya menjalankan kewajibannya sebagai kader. Hal ini disebabkan karena mereka mempunyai pekerjaan yang lainnya. Terkadang sikap mereka menjadi tak acuh terhadap kejadian penyakit DBD di daerahnya.

Tenaga kader kesehatan program DBD Puskesmas Kasihan II Bantul sudah menjalankan upaya pengendalian DBD. Akan tetapi perilaku pengendalian DBD oleh kader di wilayah kerja Puskesmas Kasihan II kurang maksimal, karena masih ada kader yang tidak mengikuti evaluasi pengendalian setiap bulannya. Sehingga mengakibatkan pelaporan terlambat. Tujuan Penelitian adalah untuk membuktikan adanya pengaruh antara sikap kader kesehatan terhadap perannya dalam 
Sri Sularsih Endartiwi, Desya Amirti Sofarina : Pengaruh Sikap Kader Kesehatan ....

pengendalian demam berdarah dengue di wilayah kerja Puskesmas Kasihan II Bantul.

\section{METODE}

Jenis penelitian ini adalah penelitian survei dengan menggunakan mix method dengan rancangan penelitian cross-sectional. Jumlah sebanyak 175 kader kesehatan yang sudah ditunjuk dan dilatih oleh puskesmas di desa Ngestiharjo wilayah kerja Puskesmas Kasihan II Kabupaten Bantul. Sedangkan subjek penelitian ini sebanyak 3 orang kader, 3 orang masyarakat dan 2 orang pegawai puskesmas dilakukan wawancara mendalam (indept interview). Penelitian dilaksanakan di Wilayah Kerja Puskesmas Kasihan II Kabupaten Bantul. Penelitian dilakukan pada Bulan Februari 2017. Varibel bebas adalah sikap kader dan variabel terikat adalah pengendalian penyakit DBD. Instrumen yang digunakan dalam penelitian ini adalah kuesioner dan panduan wawancara. Analisis bivariat menggunakan uji Kendall's Tau.

\section{HASIL}

Distribusi responden berdasarkan usia dapat dilihat pada Tabel 1 berikut ini :

Tabel 1. Distribusi Frekuensi Usia Kader Kesehatan di Desa Ngestiharjo Kasihan Bantul Tahun 2017

\begin{tabular}{lrr}
\hline \multicolumn{1}{c}{ Umur } & Frekuensi (F) & Persentase (\%) \\
\hline 22 - 31 Tahun & 10 & 5,7 \\
$32-41$ Tahun & 38 & 21,7 \\
42 - 51 Tahun & 81 & 46,3 \\
52 -61 Tahun & 35 & 20,0 \\
62 - 71 Tahun & 11 & 6,3 \\
\hline Total & 175 & 100 \\
\hline
\end{tabular}

Berdasarkan pada Tabel 1 diketahui bahwa dari 175 responden di Desa Ngestiharjo Bantul sebagian besar berusia 42-51 tahun yaitu sebanyak 81 orang (46,3\%). Sedangkan yang berusia 22-31 tahun hanya terdapat 10 orang (5,7\%), dan usia yang lainnya antara 32 - 41 tahun terdapat 38 orang (21,7\%), usia antara 52 - 61 tahun terdapat 35 orang (20,0\%) dan untuk usia antara 62 - 71 tahun hanya terdapat 11 orang (6,3\%). Distribusi Responden Berdasarkan Pekerjaan sebagai berikut : 
Tabel 2. Distribusi Frekuensi Pekerjaan Kader Kesehatan di Desa Ngestiharjo Kasihan Bantul Tahun 2017

\begin{tabular}{|c|c|c|}
\hline Pekerjaan & Frekuensi (F) & Persentase (\%) \\
\hline Ibu Rumah Tangga & 138 & 78,9 \\
\hline Guru & 3 & 1,7 \\
\hline Buruh & 3 & 1,7 \\
\hline Swasta & 18 & 10,3 \\
\hline Penjahit & 1 & 0,6 \\
\hline Pensiunan & 2 & 1,1 \\
\hline PNS & 1 & 0,6 \\
\hline Wirausaha & 9 & 5,1 \\
\hline Total & 175 & 100 \\
\hline
\end{tabular}

Berdasarkan Tabel 2 diketahui pekerjaan responden atau kader kesehatan di Desa Ngestiharjo paling banyak adalah Ibu Rumah Tangga (IRT) yaitu, sebanyak 138 orang (78,9\%). Pekerjaan yang lainnya seperti guru hanya 3 orang (1,7\%), buruh sebanyak 3 orang (1,7\%), swasta sebanyak 18 orang (10,3\%), penjahit 1 orang (0,6\%), pensiunan sebanyak 2 orang (1,1\%), PNS sebanyak 1 orang $(0,6 \%)$ dan wirausaha sebanyak 9 orang (5,1\%). Distribusi Responden Berdasarkan Pendidikan Terakhir. Distribusi responden berdasarkan pendidikan terakhir dapat dilihat pada Tabel 3 berikut ini:

Tabel 3. Distribusi Frekuensi Pendidikan Terakhir Kader Kesehatan di Desa Ngestiharjo Kasihan Bantul Tahun 2017

\begin{tabular}{|c|c|c|}
\hline Pendidikan & Frekuensi (F) & Persentase (\%) \\
\hline SD & 11 & 6,3 \\
\hline SMP & 34 & 19,4 \\
\hline SMA & 110 & 62,9 \\
\hline Diploma & 11 & 6,3 \\
\hline Sarjana & 9 & 5,1 \\
\hline Total & 175 & 100 \\
\hline
\end{tabular}

Berdasarkan Tabel 3 dapat diketahui bahwa mayoritas kader kesehatan yang menjadi responden dalam penelitian ini berpendidikan SMA yaitu sebanyak 110 orang (62,9\%). Untuk pendidikan terakhir SD terdapat 11 orang (6,3\%), SMP terdapat 34 orang (19,4\%), Diploma sebanyak 11 orang $(6,3 \%)$ dan yang paling sedikit yaitu sarjana sebanyak 9 orang (5,1\%). Distribusi responden berdasarkan lama menjadi kader sebagi berikut : 
Sri Sularsih Endartiwi, Desya Amirti Sofarina : Pengaruh Sikap Kader Kesehatan ....

Tabel 4. Distribusi Frekuensi Lama Menjadi Kader Kesehatan di Desa Ngestiharjo Kasihan Bantul Tahun 2017

\begin{tabular}{|c|c|c|}
\hline Lama Menjadi Kader & Frekuensi (F) & Prosentasi (\%) \\
\hline 1-9 Tahun & 111 & 63,4 \\
\hline 10 - 18 Tahun & 44 & 25,1 \\
\hline 19 - 27 Tahun & 12 & 6,9 \\
\hline $28-37$ Tahun & 8 & 4,6 \\
\hline Total & 175 & 100 \\
\hline
\end{tabular}

Berdasarkan Tabel 4 dapat diketahui bahwa banyak responden yang lama menjadi kader pada rentan waktu 1-9 tahun yaitu sebanyak 111 orang $(63,4 \%)$, untuk waktu 10-18 tahun terdapat 44 orang (25,1\%), untuk waktu 19-27 tahun terdapat 12 orang $(6,9 \%)$ dan untuk waktu $28-37$ tahun hanya terdapat 8 orang $(4,6 \%)$.

Tabel 5. Distribusi Frekuensi Sikap Kader Kesehatan terhadap Penyakit Demam Berdarah di Desa Ngestiharjo Kasihan Bantul Tahun 2017

\begin{tabular}{lrrr}
\hline & Kategori Sikap & Frekuensi (F) & Persentase (\%) \\
\hline Baik & & 129 & 73,7 \\
Cukup & & 43 & 24,6 \\
Kurang & & 3 & 1,7 \\
\hline & Total & 175 & 100 \\
\hline
\end{tabular}

Berdasarkan pada Tabel 5 dapat diketahui bahwa dari 175 kader kesehatan di Desa Ngestiharjo Kasihan Bantul terdapat 129 orang (73,7\%) bersikap baik, 43 orang $(24,6 \%)$ bersikap sedang dan 3 orang (1,7\%) bersikap kurang. Hasil ini menunjukkan bahwa sebagian besar kader kesehatan di Desa Ngestiharjo Kasihan Bantul mempunyai sikap terhadap penyakit demam berdarah dalam kategori baik. perilaku pengendalian terhadap penyakit demam berdarah dengue. Distribusi frekuensi perilaku pengendalian kader kesehatan tentang penyakit demam berdarah dengue di Desa Ngestiharjo Kasihan Bantul disajikan pada Tabel 6 berikut ini:

Tabel 6. Distribusi Frekuensi Perilaku Pengendalian Kader Kesehatan Penyakit Demam Berdarah Dengue di Desa Ngestiharjo Kasihan Bantul 2017

\begin{tabular}{|c|c|c|}
\hline Kategori Perilaku & Frekuensi (F) & Persentase (\%) \\
\hline Aktif & 146 & 83.43 \\
\hline Cukup Aktif & 20 & 11.43 \\
\hline Kurang Aktif & 9 & 5.14 \\
\hline Total & 175 & 100 \\
\hline
\end{tabular}


Berdasarkan Tabel 6 dapat diketahui bahwa dari 175 kader kesehatan di Desa Ngestiharjo terdapat 146 orang $(83,43 \%)$ aktif dalam melakukan perilaku pengendalian demam berdarah dengue, 20 orang (11,43\%) cukup aktif dalam perilaku pengendalian demam berdarah dengue dan 9 orang (5,14\%) kurang aktif dalam pengendalian demam berdarah dengue. Hal ini menunjukkan bahwa sebagian besar kader kesehatan di Desa Ngestiharjo melakukan pengendalian penyakit demam berdarah dengue dalam kategori baik.

Pada tabel 7 berikut ini disajikan hasil uji crosstabulation pengaruh sikap kader kesehatan terhadap pengendalian DBD dengan uji kendall tau:

Tabel 7. Hasil Uji Crosstabulation Pengaruh Sikap Kader Kesehatan Terhadap Pengendalian DBD Dengan Uji Kendall's Tau

\begin{tabular}{lcccc}
\hline \multirow{2}{*}{ Sikap } & \multicolumn{4}{c}{ Perilaku } \\
\cline { 2 - 5 } & Aktif (\%) & $\begin{array}{c}\text { Cukup } \\
\text { Aktif (\%) }\end{array}$ & $\begin{array}{c}\text { Kurang } \\
\text { Aktif (\%) }\end{array}$ & Total \\
\hline Baik & 87.60 & 9.30 & 3.10 & 100.0 \\
Cukup Baik & 76.74 & 11.63 & 11.63 & 100.0 \\
Kurang Aktif & 0.00 & 100.00 & 0.00 & 100.0 \\
\hline Total & 83.43 & 11.43 & 5.14 & 100.0 \\
\hline
\end{tabular}

Berdasarkan Tabel 7 menunjukkan bahwa sikap kader kesehatan dengan kategori baik yang memiliki perilaku aktif sebanyak 113 responden dengan nilai persentase 87.60\%, sedangkan yang memiliki perilaku cukup aktif sebanyak 12 orang (9.30\%) dan yang memiliki perilaku kurang aktif hanya 4 responden (3.10\%). Sikap kader kesehatan dengan kategori cukup yang memiliki perilaku aktif sebanyak 33 responden (76.74\%), sedangkan kategori cukup yang memiliki perilaku cukup aktif dan kurang aktif sama-sama hanya memiliki 5 responden (11.63\%). Untuk sikap dengan kategori kurang yang mamiliki perilaku cukup aktif sebanyak 3 responden (100.0\%). 
Sri Sularsih Endartiwi, Desya Amirti Sofarina : Pengaruh Sikap Kader Kesehatan ....

Tabel 8. Hasil Uji Pengaruh Sikap Kader Kesehatan tentang DBD terhadap Pengendalian DBD dengan Uji Kendall's Tau

\begin{tabular}{|c|c|c|r|r|}
\hline \multicolumn{5}{|c|}{ Correlation } \\
\hline \multirow{3}{*}{$\begin{array}{c}\text { Kendal's } \\
\text { Tau_b }\end{array}$} & \multirow{2}{*}{ Sikap } & $\begin{array}{c}\text { Correlation } \\
\text { Coeffisient }\end{array}$ & \multicolumn{1}{c|}{ Sikap } & \multicolumn{1}{c|}{ Perilaku } \\
\cline { 3 - 5 } & & Sig. (2-Tailed) & 1,000 & 0,204 \\
\cline { 3 - 5 } & \multirow{N}{N}{} & 175 & 0,006 \\
\cline { 3 - 5 } & \multirow{2}{*}{ Perilaku } & $\begin{array}{c}\text { Correlation } \\
\text { Coeffisient }\end{array}$ & 0,204 & 175 \\
\cline { 3 - 5 } & & Sig. (2-Tailed) & 0,006 & 1,000 \\
\cline { 3 - 5 } & & $\mathbf{N}$ & 175 & 175 \\
\hline
\end{tabular}

Berdasarkan Tabel 8 hasil uji statistik menggunakan uji Kendall's Tau diperoleh hasil nilai p-value diperoleh 0,006 dengan nilai $\alpha(0,05)$. Hal ini menunjukkan bahwa 0,006 $<0,05$ maka $\mathrm{H}_{\mathrm{o}}$ ditolak dan $\mathrm{H}_{\mathrm{a}}$ diterima yang berarti ada pengaruh signifikan antara sikap terhadap perilaku pengendalian demam berdarah dengue. Kekuatan pengaruh variabel pada hubungan sikap terhadap perilaku pengendalian demam berdarah dengue menunjukkan interprestasi koefisien korelasi nilai r $(0,204)$ yang berarti tingkat hubungan rendah.

Pada correlation Coefficient yaitu 0,204 dan p-value sebesar 0,006. Hal ini menunjukkan 0,006 < 0,05 yang berarti terdapat pengaruh yang positif sebesar 0,204 atau 20,4\% antara sikap terhadap perilaku pengendalian demam berdarah dengue. Hasil ini menunjukkan bahwa semakin baik sikap kader kesehatan di Desa Ngestiharjo maka akan semakin tinggi perilaku pengendalian demam berdarah dengue.

\section{Wawancara Mendalam}

Sikap Kader di wilayah kerja Puskesmas Kasihan II sudah baik di dalam melaksanakan program pengendalian dan pencegahan demam berdarah dengue di daerahnya. Berikut ini kutipan wawancaranya:

"Kalau kita begitu ada informasi kalau ada warga yang terkena DBD kita kemudian melakukan sidak di sekitar itu biasanya nantikan nyamuknya masih ada disitu, nah di lingkungan eеeеee warga yang kena itu langsung kita bersihkan 
seperti itu apayah biar tidak kemana mana biar engga ngombro-ngombro kata orang” (K1)

“Kita sepakat mengangkat isu DBD ini menjadi eeee tanggung jawab kita bersama menjadi prioritas kita bersama antara petugas, kader dan masyarakat di puskesmas kasihan dua ini. Kader juga mempunyai peranan penting di sini, sikap kader yang baik akan dapat ikut mengendalikan kasus DBD di sini.” (P1)

“Dua minggu sekali itu ada jumatik itu lho ada sidak ada perkumpulan sidak, sinikan masih ada dua minggu sekali dari satu pedukuhan masih aktif'. (M1)

Program yang dilakukan oleh kader dalam mencegah terjadinya demam berdarah dengue di wilayah kerja Puskesmas Kasihan II adalah melakukan sidak, jumantik dan melakukan kegiatan PSN. Berikut ini kutipan hasil wawancaranya:

“Ya Pertama Sidak.” (K2)

“Ya cuman jumantik aja ya, selalu PSN.” (K3)

Dukungan masyarakat terhadap program pencegahan terjadinya demam berdarah dengue cukup bagus dan masyarakat sudah menerima dengan baik program yang diterapkan oleh pihak Puskesmas Kasihan II. Berikut ini hasil kutipan wawancaranya:

"Dukungan masyarakat cukup bagus dan masyarakat sekarang sudah itu dapat dibuktikan pada saat kita door to door kunjungan rumah itu begitu kulo nuwun itu masyarakat sudah welcome.” (P1)

“Mereka sangat support sekali iya mereka senang dengan adanya program ini." (K1)

"Ya malah mendukung sekali itu, dari petugas malah menganjurkan malah enga setiap bulan ya malah setiap minggu harusnya” (K2)

"Alhamdulillah itu ada respon juga dari masyarakat ya walaupun engga semuanya cuman yang terutama yang dari kader semua berjalan bagus cuman yang masyarakat memang ada yang biasalah orang kampung ada yang engga setuju setiap hari dilihat jntiknya.” (K3) 
Sri Sularsih Endartiwi, Desya Amirti Sofarina : Pengaruh Sikap Kader Kesehatan ....

\section{Hambatan terhadap Program Pencegahan Demam Berdarah Dengue}

Pelaksanaan program pencegahan penyakit demam berdarah dengue dijumpai beberapa hambatan, akan tetapi hambatan tersebut tidak terlalu menghalangi pelaksanaan program. Berikut ini kutipan wawancara dengan beberapa informan: "Mungkin kalo penghambatnya mungkin bagi yang kerja kayak apa yang jarang di rumah ”.itu mungkin mereka kurang tau sosialisasi tentang itu.” (M3)

“Semua mendukung, kita semua punya semangat pokoknya yang kader itu punya panggilan relawan itu semuanya enga ada yang istilahnya males-males yang dari kader kami alhamdulillah semuanya bagus mau ya kadang kan ya pas ada kerjaan ya memang ditunda besok tapi berjalan.” (K3)

“Tidak ada, kita semua support. Kita semua kadernya kan banyak mba kita dari per RT itu kadang ada 4-5 orang kita ada 14 RT ketika sidak kan kita banyak sekali kader mba untuk kader jumantik itu nah disitu nanti kita bagi eеeee beberapa kelompok untuk sidak di eeee misalnya sekarang ketempatan RT 1 nanti yang disidak sekitarnya RT1 RT2 RT3 RT4 kita kelompokkan mereka pada muter seperti itu.” (K1)

“Banyak sekali faktor-faktor yang mempengaruhi ya yang pertama mobilitas penduduk sangat tinggi, kepadatannya tinggi dan kelembapannya cenderung lembab jadikan nyamuk seneng sekali didaerah yang lembab iya itu tadi kesadaran masyarakat kurang itu aja sih.” (P2)

"Yang menjadi hambatan itu pada saat kita itu sudah ketahuan positif kemudian lapor ke dinas kesehatan fogginggnya itu kadang-kadang terlalu lama, tidak langsung dari puskesmas, hambatan selanjutnya disini itu banyak rumah-rumah kosong yang ditinggalkan jadi pada saat keliling bisa jadi yang rumah kosong itu sarang nyamuk.” (P1)

\section{PEMBAHASAN}

Berdasarkan hasil analisis univariat tentang sikap kader terhadap penyakit demam berdarah dengue menunjukkan bahwa sebagian besar kader kesehatan di Desa Ngestiharjo dalam kategori baik. Sikap seseorag terhadap suatu objek merupakan reaksi seseorang yang masih tertutup. Sikap secara nyata 
menunjukkan konotasi adanya kesesuaian reaksi terhadap stimulus tertentu. Sikap belum merupakan suatu tindakan atau aktivitas, akan tetapi merupakan salah satu faktor predisposisi dari suatu perilaku seseorang (Notoatmodjo, 2010).

Pada hasil penelitian ini ditinjau dari distribusi frekuensi sikap dapat diketahui bahwa responden yang memiliki sikap baik sebanyak 129 responden (73,7\%). Sedangkan yang memiliki sikap kurang kurang baik berjumlah 3 responden (1,7\%). Sikap yang baik merupakan cerminan dari sikap positif. Sikap positif kecenderungan tindakan adalah mendekati, menyenangi terhadap suatu objek (Wawan, A dan Dewi, M., 2011).

Menurut teori Green, sikap termasuk dalam faktor predisposisi, dimana faktor predisposisi mempengaruhi atau melatarbelakangi adanya perilaku. Sehingga sikap juga dapat mempengaruhi adanya perilaku. Berbagai faktor yang dapat mempengaruhi sikap diantaranya adalah pengalaman pribadi, pengaruh orang lain yang dianggap penting, kebudayaan media masa, lembaga pendidikan dan emosional (Wawan, A dan Dewi, M., 2011). Pengalaman pribadi akan lebih mudah membentuk sikap apabila melibatkan emosi, karena penghayatannya akan lebih mendalam, lama dan berbekas. Adanya informasi dari media masa yng bersifat sugestif, sehingga mampu memberi landasan kognitif baru terbentuknya arah sikap tertentu. Sikap kader kesehatan yang baik akan meningkatkan peranannya di dalam upaya pengendalian DBD di Desa Ngenstiharjo.

Hasil penelitian ini bahwa sikap memiliki pengaruh yang signifikan dengan perilaku pengendalian demam berdarah dengue. Hal ini dapat diketahui dari nilai korelasi kendall's tau sebesar 0,204 dengan sig. 0,006 < $\alpha(0,005)$. Hasil ini mempunyai arti bahwa semakin baik sikap kader kesehatan tentang penyakit demam berdarah dengue maka semakin baik pula dalam melakukan pengendalian demam berdarah dengue. Hal ini sesuai dengan pendapat bahwa perilaku yang didasari dengan pengetahuan, kesadaran dan sikap yang baik, maka perilaku taersebut akan bersifat long lasting. Sikap berhubungan motivasi individu untuk melakukan kegiatan pengendalian demam berdarah dengue (Notoatmodjo, 2010).

Hasil penelitian juga masih menunjukkan bahwa masih terdapat kader kesehatan di Desa Ngestiharjo yang kurang aktif dalam melakukan pengendalian 
demam berdarah dengue. Padahal peranan dari kader kesehatan untuk melakukan pengendalian penting untuk menghilangkan pemutusan rantai penularan penyakit demam berdarah dengue (Proverawati, dkk., 2012). Peran kader tersebut yaitu memanfaatkan setiap kesempatan di desa/kelurahan untuk memberikan penyuluhan tentang pencegahan penyakit demam berdarah dengue misalnya melalui penyuluhan kelompok di posyandu, pertemuan kelompok dasa wisma, arisan, pengajian, pertemuan desa/kelurahan, kunjungan rumah dan melalui media cetak (poster, selebaran, spanduk).

Bersama pemerintah desa atau kelurahan tokoh masyarakat untuk melaksanakan PSN. Melakukan pemeriksaan jentik berkala secara teratur setiap minggu dan mencatat angka jentik yang ditemukan pada kartu jentik rumah. Mengumpulkan data angka bebas jentik dari setiap rumah tangga yang ada di wilayah kerja dan melaporkan secara rutin kepada puskesmas terdekat untuk mendapat tindak lanjut penanganan bila terjadi masalah/kasus. Menginformasikan angka jentik yang ditemukan kepada setiap rumah tangga yang dikunjungi sekaligus memberikan penyuluhan agar tetap melaksanakan pemberantasan sarang nyamuk secara rutin dan menegur secara baik apabila masih terdapat jentik nyamuk.

Penelitian ini didukung oleh penelitian Santhi, dkk (2014) menyatakan bahwa semakin kooperatif sikap responden semakin baik aktivitas pemberantasan sarang nyamuk. Hal ini dipertegas dengan pengujian hipotesis menggunakan chi square sebesar 36,670 dan nilai $\mathrm{p}=0,00$ yang berarti $\mathrm{H}_{\mathrm{a}}$ diterima dan $\mathrm{H}_{0}$ ditolak dengan kata lain bahwa ada pengaruh sikap masyarakat tentang penyakit demam berdarah dengue terhadap aktivitas pemberantasan sarang nyamuk di Desa Dalung Kecamatan Kuta Utara.

Suatu sikap belum otomatis terwujud dalam bentuk praktik. Untuk terwujud sikap agar menjadi suatu perbuatan yang nyata (praktik) diperlukan faktor pendukung atau kondisi yang memungkinkan. Berdasarkan uraian teori-teori tersebut, menunjukkan adanya pengaruh antara sikap dengan aktivitas pemberantasan sarang nyamuk disebabkan karena yang didasari oleh baiknya tingkat pengetahuan yang dimiliki (Notoatmodjo, 2007). 
Berdasarkan informasi yang diperoleh dari wawancara kepada kader kesehatan dan petugas puskesmas menunjukkan bahwa peranan dari kader kesehatan terhadap upaya pengendalian DBD di Desa Ngestiharjo sangatlah besar. Sikap kader yang selalu sigap dan cepat dalam menanggapi kasus DBD dapat mencegah terjadinya kasus kematian. Selain itu dukungan dari masyarakat terhadap kegiatan yang dilakukan oleh kader kesehatan juga sangat membantu berlangsungnya program pengendalian DBD di Desa Ngestiharjo wilayah kerja Puskesmas Kasihan II.

Kunci pencegahan penyakit DBD adalah pengawasan yang ketat untuk pelaporan dini hasil pemantauan kepadatan vektor. Peran jumantik sangat penting dalam sistem kewaspadaan dini DBD karena berfungsi untuk memantau keberadaan serta menghambat perkembangan awal dari vektor penular DBD. Keaktifan kader jumantik dalam memantau lingkungannya merupakan langkah penting untuk mencegah meningkatnya angka kasus DBD (Pratamawati, 2012).

Hasil yang lain menunjukkan bahwa sikap tidak ada hubungan yang signifikan dengan peran tokoh masyarakat. Peran masyarakat yang tidak didasari dengan pengetahuan dan sikap yang positif, ataupun sikap positif dan tahu saja tetapi belum dicerminkan dalam perannya pada pengendalian demam berdarah mungkin saja menjadi salah satu penyebab sulit tertanggulanginya masalah demam berdarah (Bahtiar, 2012).

Upaya untuk penanggulangan penyakit DBD memerlukan partisipasi aktif masyarakat secara berkesinambungan. Hal ini merujuk bahwa DBD adalah penyakit yang berbasis lingkungan yang dapat menular dari sumber penularan orang yang terinfeksi virus dengue ke orang yang sehat melalui perantaraan nyamuk Ae. aegypti sebagai vektor. Lingkungan rumah yang bebas dari tempat perindungan nyamuk Ae.aegypti, secara potensial tetap berisiko tinggi untuk terjadi penularan, apabila lingkungan sekitar tidak bersih. Partisipasi masyarakat tersebut dapat berupa kebiasaan membersihkan lingkungan berupa gerakan 3M yang meliputi kebiasaan menimbun, menguras dan menutup tempat penampungan air serta kebiasaan tidak menggantung pakaian (Syatriani, 2009). 
Sri Sularsih Endartiwi, Desya Amirti Sofarina : Pengaruh Sikap Kader Kesehatan ....

\section{SIMPULAN}

Sikap kader kesehatan memiliki pengaruh yang signifikan terhadap perilaku pengendalian demam berdarah dengue seperti melakukan kegiatan 3M di Desa Ngestiharjo wilayah kerja Puskesmas Kasihan II Bantul. Hal ini ditunjukkan dengan hasil uji kendall's tau yang memiliki p-value 0,006. Kader kesehatan sudah baik melakukan kewajibannya untuk pencegahan penyakit Demam Berdarah Dengue di Desa Ngestiharjo wilayah kerja Puskesmas Kasihan II Bantul. Hal ini dapat mengurangi kejadian demam berdarah dengue di wilayah ini.

\section{UCAPAN TERIMA KASIH}

STIKES Surya Global Yogyakarta atas bantuan dana untuk melaksanakan penelitian ini.

\section{DAFTAR PUSTAKA}

DINKES Provinsi DIY. 2014. Profil Kesehatan Provinsi DIY Tahun 2014. DIY : Dinkes Prov DIY

DINKES Kabupaten Bantul. 2015. Profil Kesehatan Kabupaten Bantul Tahun 2015. Bantul : Dinkes Kab Bantul

Notoatmodjo, Soekidjo. 2010. Promosi Kesehatan Teori dan Aplikasi. Jakarta: PT Rineka Cipta

Wawan, A dan Dewi, M. 2011. Teori dan Pengkuran Pengetahuan, Sikap, dan Perilaku Manusia. Yogyakarta: Nuha Medika

Proverawati, Atikah dan Rahmawati, Eni. 2012. Perilaku Hidup Bersih dan Sehat. Yogyakarta: Nuha medika

Santhi, Ni Made Murtini; Darmadi, I Gede Wayan; Aryasih, IGAM. 2014. Pengaruh Pengetahuan dan Sikap Masyarakat Tentang DBD Terhadap Aktivitas Pemberantasan Sarang Nyamuk di Desa Dalung Kecamatan Kuta Utara Tahun 2012. Jurnal Kesehatan Lingkungan Vol. 4 No.2, November 2014.

Notoatmodjo, Soekidjo. 2007. Kesehatan Masyarakat Ilmu dan Seni. Jakarta: PT Rineka Cipta

Pratamawati, Diana Andriyani. 2012. Peran Juru Pantau Jentik dalam Sistem Kewaspadaan Dini Demam Berdarah Dengue di Indonesia. Jurnal Kesehatan Masyarakat Nasional Vol.6 No.6, Juni 2012. DOI httpdx.doi.org10.21109kesmas.v6i6.76

Bahtiar, Yanyan. 2012. Hubungan Pengetahuan dan Sikap Tokoh Masyarakat dengan Perannya Dalam Pengendalian Demam Berdarah Dengue di Wilayah Puskesmas Kawalu Kota Tasikmalaya. Aspirator Vol.4 No.2 Tahun 2012 Hal. 73-84. Penerbit Loka Litbang P2B2 Ciamis. 
Syatriani, Sri; Puji, Esse; Susilowati, Andi. 2009. Partisipasi Masyarakat Menanggulangi Lingkungan Demam Berdarah Dengue di Kecamatan Rappocini Kota Makasar. Jurnal Kesehatan Masyarakat Nasional Vol.3, No.5, April 2009. DOI httpdx.doi.org10.21109kesmas.v3i5.213. 